\title{
The Predictive and Incremental Validity of Psychological Empowerment Dimensions on Teachers' Career Commitment beyond Autonomy, Competence and Relatedness
}

\author{
Dr. Sesan O. Mabekoje ${ }^{1^{*}}$ \\ Dr. R. Olugbenga Azeez ${ }^{1}$ \\ Dr. Abel O. Bamgbose ${ }^{2}$ \\ Dr. Olusola O. Okunuga ${ }^{3}$ \\ ${ }^{1}$ Faculty of Education, Olabisi Onabanjo University, \\ Ago Iwoye, Nigeria \\ ${ }^{2}$ Ogun State Television, Abeokuta, Nigeria \\ ${ }^{3}$ Faculty of Social and Management Sciences, \\ Olabisi Onabanjo University, Ago-Iwoye, Nigeria \\ ${ }^{*}$ Correspondance Author
}

Doi: $10.1515 / \mathrm{mjss}-2017-0018$

\section{Abstract}

This study examined the predictive and additive effects of psychological empowerment dimensions on teachers' career commitment over and above the satisfaction of basic work needs of autonomy, competence and relatedness. Two hundred and twelve teachers, selected through a stratified random sampling technique took part in the survey. The Career Commitment Measure, Basic Needs Satisfaction at Work Scale, and Psychological Empowerment Instrument were used to collect data which were analyzed using Moderated Hierarchical Multiple Regression Analysis. Findings indicated that psychological needs satisfaction had predictive effect on teachers' career commitment $\left(R^{2}=.233 ; p<\right.$ .001). Psychological empowerment had both predictive and incremental effects on teachers' career commitment $\left(R^{2}=.286 ; \Delta R^{2}=.053 ; p<.001\right)$, accounting for a significant add-on effect of 5.3 percent of the variance in teachers' career commitment over the effect of autonomy, competence and relatedness. Empowering teachers psychologically has both predictive and add-on effects on teachers' career commitment beyond the contribution of autonomy, competence and relatedness. Recommendations were made for research and practice.

Keywords: Career Commitment, Psychological Empowerment, Psychological needs satisfaction, Moderated Hierarchical Multiple Regression Analysis

\section{Introduction}

Much emphasis has always been placed on the role of teachers in National development. In fact, it has been alluded that no Nation can develop beyond the quality of its teachers. The world over, the success of educational reforms for National development had been found to be possible only with teachers who are empowered and committed. The present education programme in Nigeria would be particularly successful when teachers who are to implement the programme are psychologically empowered, having their basic work psychological needs satisfied and committed to their career.

Career commitment has been described as one's attitude to one's profession or vocation (Freund, 2005). This is defined as a psychological link that an individual worker has with their 
chosen profession (Okurame, 2012). Based on the works of Blau (1985), Greenhaus (1971), Hall (1971) and London (1983), Carson and Bedeian (1994) suggest another multifactor concept of career commitment which comprise of three components including career identity, career planning, and career resilience. Career identity pertains to establishing a close emotional relationship with one's career, while career planning determines one's developmental needs and setting career goals and career resilience involves resisting career disturbance in the face of misfortunes (Ciceka , Karabogab, \& Sehitoglu, 2016; Kidd \& Green, 2006; Mabekoje, Azeez, Okunuga, \& Bamgbose, 2016; Onyoin, 2011).

Career commitment relates positively to such indices as skill development (Aryee \& Tan, 1992), job performance (Aryee \& Tan, 1992; Somers \& Birnbaum, 1998; 2000), job involvement (Goulet \& Singh, 2002), career success (Day \& Allen, 2004), career satisfaction (Carson, Carson, Roe, Birkenmeier \& Phillips, 1999), and organizational commitment (Cohen, 1996; Weiner \& Vardi, 1980 ) but negatively related to job withdrawal cognitions and actual turnover (Bedeian, Kemery, \& Pizzolatto, 1991). In a meta-analysis, career commitment was found to strongly relate with job involvement, organizational commitment, job satisfaction, burnout, and career satisfaction. Moderate relationship was noted with stress, role ambiguity, role conflict, supervisor support, coworker support, job autonomy, participation, and locus of control. However, weak or no relationship were observed between career commitment and variables as age, gender, occupational tenure, organizational tenure, education, marital status, number dependents, and income (Lee, Carswell, \& Allen, 2000).

Career commitment would be influenced by having a mentor (Colarelli \& Bishop, 1990), potential for greater income and higher self- esteem (Kalbers \& Forgarty, 1995), career satisfaction (Aryee \& Tan, 1992; Fu, 2011). Career commitment also predicts such variables like learning motivation and learning transfer (Cheng \& Ho, 2001), career success (Kidd \& Green, 2006; Poon, 2004) and career satisfaction through self-efficacy (Ballout, 2009).

The construct of work-related basic needs satisfaction has been mostly studied within organisational rather that educational settings. Psychological needs are defined as the nutrients or conditions that are essential to an entity's growth and integrity (Ryan, 1995; Van den Broeck, Vansteenkiste, DeWitte \& Lens, 2008). Basic to Self-Determination Theory (SDT) is the notion that the satisfaction of the basic psychological needs is fundamental to promoting the internalization of cultural norms and values into a coherent self-structure (Wilson, Longley, Muon, Rodgers, \& Murray, 2006). The self-determination theory classified basic needs as autonomy, competence and relatedness (Deci \& Ryan, 1985; 2000; Ryan \& Deci, 2000). The need for autonomy represents individuals' inherent desire to act with a sense of choice and volition, that is, to be the author of one's actions and to feel psychological free (Van den Broeck, Vansteenkiste, \& De Witte, 2008). The need for competence is defined as individuals' inherent desire to feel effective in interacting with the environment (Van den Broeck, Vansteenkiste, De Witte, Soenens, \& Lens, 2010). The need for relatedness is defined as individuals' inherent propensity to feel connected to others, that is, to be a member of a group, to love and care and be loved and cared for (Baumeister \& Leary, 1995; Van den Broeck et al., 2008).

The satisfaction of the basic psychological needs is therefore innate, universal and exert positive influence on well-being (Deci \& Ryan, 2002; Harris \& Hagger, 2007; Wilson et al., 2006). Individuals have basic needs which must be satisfied if they are to function effectively and be happy. Within work context, the satisfaction of the basic psychological needs correlate positively with favorable work outcomes (Baard, Deci, \& Ryan, 2004). Particularly, basic psychological needs correlate positively with job satisfaction (llardi, Leone, Kasser, \& Ryan, 1993; Mayer, Bardes, \& Piccolo, 2008), employee well-being (Lynch, Plant \& Ryan, 2005), performance evaluations (Baard et al., 2004), vigor (Van den Broeck et al., 2008), dedication (Vansteenkiste et al., 2007), and affective organizational commitment (Greguras \& Diefendorff, 2009). However, basic needs satisfaction relates negatively with emotional exhaustion (Van den Broeck et al., 2008). The satisfaction of basic needs predicts work engagement; as in vigour and dedication (Van den Broeck et al., 2008), job satisfaction (llard et al.,1993) and job performance (Baard et al.,2004). The satisfaction of the basic work needs of teachers would be expected to play important role in their career commitment. 
Overtime, there has been two complementary perspectives on work empowerment. The first was the focus on the socio-structural conditions which permits empowerment whereas the second was on the psychological experience of empowerment at work (Liden \& Arad, 1996). This study focuses on psychological empowerment. Psychological empowerment has been described as individual subjective feeling of competence, responsibility and greater control over one's life (Bracht, 1999; Mabekoje et al., 2016; Rissel, 1994; Wallerstein, 1992). This in essence means that the individual moves towards autonomy and being able to decide owns plan (Mabekoje et al., 2016; Tengland, 2007).

Psychological empowerment therefore is a motivational construct (Dewettinck, Singh, \& Buyens, 2003; Nel, Stander, \& Latif, 2015; Spreitzer, 1995a; Spreitzer, Kizilos, \& Nason, 1997; Thomas \& Velthouse, 1990) that includes the degree of meaning, competence, self-determination and impact (Keller, 2005). Meaning involves congruence between the needs of one's work roles and one's personal beliefs, values and behaviours. Competence on the other hand refers to selfefficacy which is specific to one's work. That is one's belief in his/her capacity to perform work activities with skills. Self-determination involves initiating and regulation of one's actions (Spreitzer, 1995b). Impact however is the degree to which a person can influence strategic, administrative or operating outcomes at work (Ashforth, 1989; Fields, 2002; Spreitzer, 1995b; 1996).

Relationships have been observed between feeling of psychological empowerment and such personal variables as level of education (Koberg, Senjem, \& Goodman, 1999; Spreitzer, 1996), gender (Boudrias, Gaudrean, \& Laschinger, 2004), age (Ozaralli, 2003), status/position or rank (Ergeneli, Ari, \& Metin, 2007; Koberg et al., 1999) and organizational variables such as job strain (Parker, 1993; Spreitzer et al., 1997; Straw, 1984; Thomas \& Tymon, 1994), organisational citizenship behaviour (Najafi, Noruzy, Azar, Nazari-Shirkouhi, \& Dalvand, 2011; ShapiraLishchinsky \& Tsemach, 2014), job involvement (Saeidi \& Asgari, 2016), job satisfaction (Hackman \& Oldham, 1980; Liden, Wayne \& Sparrowe, 2000; Thomas \& Velthause, 1990), managerial effectiveness, productivity or job performance (Liden et al., 2000; Liden, Wayne, \& Stilwell, 1993; Spreitzer, 1995a; Thomas \& Velthouse, 1990). For theory and practice alike, the premise of empowerment has been to have satisfied, committed and highly performing employees (Dewettinck \& Buyens, 2006; Dewettinck et al., 2003).

There are enormous benefits therefore why workers' empowerment should be taken seriously by organizations. Psychological empowerment has been found to predict job performance (Kimolo, 2013; Seibert, Silver, \& Randolph, 2004), job satisfaction and productivity (Carless, 2004; Greasley et al., 2005), employee engagement (Jose \& Mampilly, 2014; Kosar \& Mehdi Raza Naqvi, 2016; Stander \& Rothmann, 2010) and organisational identity (Prati \& Zani, 2013).

Emerging research demonstrates that teacher empowerment along with other work variables are critical to increasing student achievement and retaining teachers (Hirsch \& Emerick, 2006). It is however unfortunate that despite decades of academic and practitioner attention on the construct of empowerment, the received wisdom is scepticism (Dewettinck et al., 2003). For teachers to be truly empowered, they need a supporting environment in which they are cared for, not isolated and are given the opportunity to participate regularly in decision making that affects them as teachers (Mabekoje et al., 2016; Wenzlaff \& Wieseman, 2004). The satisfaction of the basic psychological needs therefore stands as the foundation for the feeling of psychological empowerment.

This study was therefore determined whether there are predictive and incremental effects of psychological empowerment dimensions on teachers' career commitment, over and beyond the satisfaction of autonomy, competence and relatedness. It was therefore hypothesised that there would be a significant predictive and add-on effect of psychological empowerment dimensions on teachers' career commitment over the satisfaction of autonomy, competence and relatedness.

\section{Method}

\subsection{Participants}

The participants for this study include 212 teachers selected through a stratified random sampling process. A list of all secondary schools in ljebu North Educational Zone of Ogun State, Nigeria was 
made. Out of the existing 36 schools, 24 were selected by random sampling method. Twelve schools each were selected from each of the two political sections of the educational zone. Teachers who gave verbal consent were sampled to participate in the study.

Table 1 presents the demographic distribution of the study participsants by sex, age, highest qualification and work experience.

Table 1: Respondents by the demographic factors.

\begin{tabular}{clcc}
\hline \multicolumn{1}{c}{ Variables } & $\mathrm{N}$ & $\%$ \\
\hline Sex & & \\
Male & 58 & 27.4 \\
Age & 154 & 72.6 \\
& & \\
& Below 35 years & 153 & 72.2 \\
35 to 45 years & 52 & 24.5 \\
46 to 55 years & 4 & 1.9 \\
Above 55 years & 3 & 1.4 \\
Highest Qualification & & \\
NCE & 86 & 40.6 \\
Bachelor's Degree & 106 & 50.0 \\
Master's Degree & 12 & 5.7 \\
Others & 8 & 3.8 \\
Work Experience & & \\
$\quad$ Below 5 years & 122 & 57.5 \\
6 - 10 years & 55 & 25.9 \\
11 - 15 years & 18 & 8.5 \\
16 - 20 years & 8 & 3.8 \\
Above 20 years & 9 & 4.2 \\
\hline
\end{tabular}

\subsection{Measures}

\subsubsection{Career Commitment Measure.}

We measured career commitment using the Career Commitment Measure (CCM) developed by Carson and Bedeian (1994). The scale is a 12-item self-report instrument which measures threedimensional factors of career identity (4 items e.g. I strongly identify with my chosen line of work/career field), career planning (3 items e.g. I do not identify specific goals for my development in this line of work/career field) and career resilience (5 items: e.g. The cost associated with my line of work/career field sometimes seems too great). The scale was anchored on a 5-point Likert scale ranging from $1=$ strongly disagree to $5=$ strongly agree. Reliability coefficients for the three factors ranged from 0.79 to 0.85 (Carson \& Bedeian, 1994; Mabekoje et al., 2016).

\subsubsection{Basic Psychological Needs at Work Scale.}

We assessed psychological needs satisfaction using the Basic Psychological Needs at Work Scale developed by Deci et al. (2001). The scale is a 21-item questionnaire designed to assess the extent to which employees experience satisfaction on their job along three intrinsic needs of autonomy ( 7 items e. g. "I feel like I can pretty much be myself at work"), competence (6 items e. g. "Most days I feel a sense of accomplishment from working") and relatedness (8 items e. g. People at work are pretty friendly towards me"). The participants responded on 7-point Likert-type format ranging from $1=$ not at all true to $7=$ very true. The Cronbach's alpha ranging from .62 to .79 for autonomy, .73 to .81 for competence, and .57 to .84 for relatedness. Alpha coefficients from .83 to .89 has been reported for the total need-satisfaction. Intrinsic need satisfaction have been found to correlate positively with work performance ratings and with psychological adjustment (Baard et al., 2000). 


\subsubsection{Psychological Empowerment Instrument.}

We assessed psychological empowerment using the Psychological Empowerment Instrument designed by Spreitzer (1995a) to measure Thomas and Velthouse's (1990) four-dimensional definition of psychological empowerment of meaning (e.g "The work I do is meaningful"), competence (e.g "I have mastered the skills necessary to do my job"), self-determination (e.g "I can decide on my own how to go about doing my work"), and impact (e.g "I have a great deal of control over what happens in my department"). The 12 items (three items per dimension) self-report questionnaire was anchored on a 7-point Likert Scale with responses ranging from $1=$ very strongly disagree to 7 = very strongly agree.

Evidence of criterion-related validity shows that subscale scores were significantly but moderately related to career intentions and organizational commitment. Also, internal consistency ranges from .79 to .85 for the subscales and from .62 to .74 for the total scale (Mabekoje et al., 2016). Higher score indicates higher perception of empowerment.

\subsection{Procedure}

The researchers personally administered the research instruments to the participants in their various schools. Permission was sought from the Principals of the sampled schools for the conduct of the study. Participants were met at their staff rooms and addressed on the purpose of the study. Participants were also acquainted with the fact that their responses would be kept confidential and used strictly for the purpose of the research. Data obtained from the instruments were analysed using both descriptive and inferential statistics. Mean and standard deviation as well as Pearson Product Moment Correlation Coefficient were done to present the nature of data on study variables. Independent t-test and Analysis of Variance were also used to determine differences in study variables along demographic factors. The research hypothesis was analysed using the Moderated Hierarchical Multiple Regression Analysis.

\section{Results}

\subsection{Preliminary Analysis}

Table 2 presents the minimum and maximum scores as well as the mean scores and standard deviation for each of the variables of the study.

Table 2: Descriptive statistics including the minimum and maximum scores, mean scores and standard deviation among study variables $(\mathrm{N}=212)$

\begin{tabular}{llccc}
\hline & & Min. - Max & Mean & SD \\
\hline 1 & Career commitment & $12.00-60.00$ & 43.033 & 7.572 \\
2 & Autonomy & $15.00-47.00$ & 32.693 & 6.556 \\
3 & Competence (BPN) & $16.00-42.00$ & 33.269 & 6.291 \\
4 & Relatedness & $22.00-56.00$ & 40.797 & 6.511 \\
5 & Meaning & $3.00-21.00$ & 18.547 & 4.273 \\
6 & Competence (PE) & $3.00-21.00$ & 17.995 & 4.431 \\
7 & Self determination & $3.00-21.00$ & 14.915 & 4.651 \\
8 & Impact & $3.00-21.00$ & 14.156 & 4.916 \\
\hline
\end{tabular}

Table 3 presents the Pearson Product Moment Correlation Coefficients of Interrelationship of study variables. 
Table 3: Bivariate Correlations of variables of the study

\begin{tabular}{|c|c|c|c|c|c|c|c|c|c|}
\hline & & 1 & 2 & 3 & 4 & 5 & 6 & 7 & 8 \\
\hline 1 & Career commitment & 1 & $.302 "$ & $.455^{\mathrm{Nm}}$ & $.273^{* * m}$ & $.310^{* m}$ & $.342^{\mathrm{min}}$ & .093 & $.255^{\pi+14}$ \\
\hline 2 & Autonomy & & 1 & $.334^{* * \pi}$ & $.423^{* * *+}$ & $.246^{* * *}$ & $.279^{\mathrm{com}}$ & $.264^{m *+}$ & $.242^{* * *+}$ \\
\hline 3 & Competence (BPN) & & & 1 & $.450^{* * *+}$ & $269^{* * *}$ & $.428^{* *+*}$ & $.140^{*}$ & $.192^{* *}$ \\
\hline 4 & Relatedness & & & & 1 & $270^{* * * *}$ & $.418^{* * *+}$ & $.192^{* *}$ & $.157^{*}$ \\
\hline 5 & Meaning & & & & & 1 & $.671^{\mathrm{cms}}$ & $.320^{\mathrm{max}}$ & $.305^{\operatorname{kx}}$ \\
\hline 6 & Competence (PE) & & & & & & 1 & 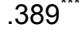 & $.334^{x \mathrm{x} x}$ \\
\hline 7 & Self determination & & & & & & & 1 & $.475^{\operatorname{xx}}$ \\
\hline 8 & Impact & & & & & & & & 1 \\
\hline
\end{tabular}

The results in Table 3 showed significant relationships among the study variables. Career commitment correlated with all the dimensions of psychological needs satisfaction; autonomy, competence, and relatedness as well as with most of the factors of psychological empowerment but for self-determination. Dimensions of psychological needs satisfaction and the factors of psychological empowerment were also positively correlated.

Analyses were carried out to determine differences in the study variables along demographic factors. Table 4 presents the results of the Independent t-test and Analysis of Variance.

Table 4: Independent t-test and Analysis of Variance of demographic differences in study variables

\begin{tabular}{|c|c|c|c|c|c|c|}
\hline & \multicolumn{2}{|c|}{ Career Commitment } & \multicolumn{2}{|c|}{ Basic Need Satisfaction } & \multicolumn{2}{|c|}{ Psychological Empowerment } \\
\hline & $\mathrm{M}$ & SD & $\mathrm{M}$ & SD & M & SD \\
\hline \multicolumn{7}{|l|}{ Sex } \\
\hline Male $(n=58)$ & 42.569 & 7.153 & 108.103 & 13.748 & 67.466 & 12.891 \\
\hline Female $(n=154)$ & 43.208 & 7.740 & 106.253 & 15.480 & 64.916 & 13.933 \\
\hline Statistics & \multicolumn{2}{|c|}{$\begin{array}{c}\mathrm{t}(210)=.547 \\
p=.585\end{array}$} & \multicolumn{2}{|c|}{$\begin{array}{c}\mathrm{t}(210)=.779 \\
p=.425\end{array}$} & \multicolumn{2}{|c|}{$\begin{array}{c}\mathrm{t}(210)=1.212 \\
p=.227\end{array}$} \\
\hline \multirow{2}{*}{\multicolumn{7}{|c|}{$\begin{array}{l}\text { Age } \\
\text { below } 35 \text { years }(n=153)\end{array}$}} \\
\hline & 42.902 & 7.460 & 106.595 & 15.128 & 64.863 & 14.487 \\
\hline 35 to 45 years $(n=52)$ & 43.442 & 7.996 & 108.403 & 14.857 & 68.000 & 10.356 \\
\hline 46 to 55 years $(n=4)$ & 47.000 & 6.976 & 105.500 & 8.266 & 73.500 & 7.326 \\
\hline above 55 years $(n=3)$ & 37.333 & 5.508 & 88.333 & 9.074 & 52.000 & 19.079 \\
\hline Statistics & \multicolumn{2}{|c|}{$\begin{array}{c}\mathrm{F}(3,208)=.998 \\
p=.395\end{array}$} & \multicolumn{2}{|c|}{$\begin{array}{c}\mathrm{F}(3,208)=1.747 \\
p=.158\end{array}$} & \multicolumn{2}{|c|}{$\begin{array}{c}F(3,208)=2.151 \\
p=.095\end{array}$} \\
\hline \multicolumn{7}{|l|}{ Qualification } \\
\hline NCE $(n=86)$ & 43.605 & 8.126 & 107.000 & 14.819 & 66.442 & 12.606 \\
\hline Bachelor's Degree $(n=106)$ & 43.076 & 6.951 & 106.821 & 15.216 & 65.151 & 14.443 \\
\hline Master's Degree $(n=12)$ & 39.917 & 8.522 & 103.417 & 15.906 & 58.833 & 14.154 \\
\hline Others $(n=8)$ & 41.000 & 7.892 & 108.375 & 15.408 & 73.000 & 10.447 \\
\hline Statistics & \multicolumn{2}{|c|}{$\begin{array}{c}F(3,208)=1.035 \\
p=.378\end{array}$} & \multicolumn{2}{|c|}{$\begin{array}{c}\mathrm{F}(3,208)=.234 \\
p=.872\end{array}$} & \multicolumn{2}{|c|}{$\begin{array}{c}\mathrm{F}(3,208)=1.933 \\
p=.125\end{array}$} \\
\hline \multirow{6}{*}{$\begin{array}{l}\text { Work Experience } \\
\text { below } 5 \text { years }(n=122) \\
5-10 \text { years }(n=55) \\
11-15 \text { years }(n=18) \\
16-20 \text { years }(n=8) \\
\text { above } 20 \text { years }(n=9)\end{array}$} & & & & & & \\
\hline & 42.328 & 6.934 & 106.131 & 15.553 & 64.959 & 12.206 \\
\hline & 45.000 & 7.535 & 107.618 & 14.355 & 66.309 & 16.631 \\
\hline & 41.500 & 9.326 & 106.778 & 12.360 & 68.889 & 10.632 \\
\hline & 42.875 & 8.114 & 110.375 & 14.803 & 68.500 & 10.268 \\
\hline & 43.778 & 10.929 & 106.778 & 18.919 & 61.111 & 20.319 \\
\hline Statistics & \multicolumn{2}{|c|}{$\begin{array}{c}F(4,207)=1.410 \\
p=.232\end{array}$} & \multicolumn{2}{|c|}{$\begin{array}{c}F(4,207)=.211 \\
p=.932\end{array}$} & \multicolumn{2}{|c|}{$\begin{array}{c}F(4,207)=.693 \\
\quad p=.598\end{array}$} \\
\hline
\end{tabular}

The results presented in Table 4 showed that no significant differences existed in teachers' career commitment, psychological empowerment, and basic needs satisfaction along gender, age, qualification and work experience. This in effect implies that teachers' career commitment, basic needs satisfaction, and psychological empowerment are similar, irrespective of their sex, age, qualification and work experience. 


\subsection{Moderated Hierarchical Multiple Regression Analysis}

Data were analysed using the Moderated Hierarchical Multiple Regression Analysis in order to determine the combined and separate contributions of the independent (predictor) variables to the prediction of the dependent (criterion) variable. Table 5 presents the results of data analysis.

Table 5: Effects of psychological empowerment dimensions on overall career commitment of teachers beyond autonomy, competence and relatedness

\begin{tabular}{|c|c|c|c|c|c|c|c|c|}
\hline & \multicolumn{3}{|c|}{ Step 1} & \multicolumn{3}{|c|}{ Step 2} & \multicolumn{2}{|c|}{ Collinearity Statistics } \\
\hline & $B$ & SEB & $\beta$ & $B$ & SEE & $\beta$ & Tolerance & VIF \\
\hline Autonomy & .184 & .079 & .160 & .156 & .079 & .135 & .752 & 1.330 \\
\hline Competence (BPN) & .467 & .083 & $388^{* 1+1}$ & .399 & .085 & $.331^{* * *}$ & .704 & 1.421 \\
\hline Relatedness & .035 & .084 & .030 & .001 & .084 & .001 & .669 & 1.495 \\
\hline Meaning & & & & .236 & .143 & .133 & .537 & 1.861 \\
\hline Competence (PE) & & & & .123 & .154 & .072 & .433 & 2.310 \\
\hline Self determination & & & & -.219 & .115 & -.135 & 697 & 1.435 \\
\hline Impact & & & & .243 & 107 & $158^{* *}$ & .731 & 1.368 \\
\hline & $F(3,2$ & $\begin{array}{l}R^{2}=.2 \\
08)=\end{array}$ & $\begin{array}{l}3 ; \\
.105^{* * *+}\end{array}$ & $\begin{array}{r}\mathrm{R}^{2}= \\
\mathrm{F}(7,\end{array}$ & $\begin{array}{l}6 ; \Delta \mathrm{B} \\
4)=1\end{array}$ & $\begin{array}{l}.053 \\
64 \\
64\end{array}$ & & \\
\hline
\end{tabular}

a. Dependent Variable: Career commitment

b. Predictors: (Constant), Relatedness, Autonomy, Competence (BPN)

c. Predictors: (Constant), Relatedness, Autonomy, Competence (BPN), Impact, Meaning, Self determination, Competence (PE)

$p<.05 ; * p<.01 ; p<.001$

The results presented in Table 5 revealed that basic work needs satisfaction significantly contributed to teachers' career commitment $\left(R^{2}=.233 ; F_{(3,208)}=21.105 ; p<.001\right)$. Basic work psychological needs accounted for $23.3 \%$ of the variance in teachers' career commitment. Specifically, autonomy $(\beta=.160 ; p<.05)$ and competence $(\beta=.388 ; p<.001)$ were potent contributors to teachers' career commitment while relatedness $(\beta=.030 ; p>.05)$ was not.

The introduction of psychological empowerment to the model indicated its significant predictive and additive effect on teachers' career commitment over and above the effect of basic work needs satisfaction $\left(R^{2}=.286 ; \Delta R^{2}=.153 ; F_{(7,204)}=11.664 ; p<.001\right)$. Psychological empowerment together with basic work needs satisfaction contributed $28.6 \%$ to the variance in teachers' career commitment. In effect, psychological empowerment accounted for an addition of $5.3 \%$ to the variance in teachers' career commitment over and beyond the effect of basic work needs satisfaction. Specifically, autonomy $(\beta=.135 ; p<.05)$, work needs competence $(\beta=.331 ; p$ $<.001)$ and impact $(\beta=.158 ; p<.05)$ were factors of basic work psychological needs satisfaction and psychological empowerment that are potent in the prediction of teachers' career commitment.

The tolerance values are all higher than .10 while the Variance Inflation Factors (VIF) are lower than 10. This indicates the absence of multicollinearity in the study data.

\section{Discussion}

The predictive and incremental effects of psychological empowerment dimensions on teachers' career commitment over and above the effect of autonomy, competence and relatedness were investigated in this study. Foremost, the relationships among career commitment, the dimensions of basic psychological needs satisfaction and that of psychological empowerment were examined. Except for self-determination which does not significantly correlate with career commitment, other factors of psychological needs satisfaction and the dimensions of psychological empowerment correlated significantly and positively with career commitment.

The observed relationships are not surprising. First, psychological needs satisfaction and psychological empowerment could be considered as positive constructs which, by characterization, should be positively correlated. It will not be astonishing too, that they both correlated positively with 
career commitment.

Dimensions of basic psychological needs; autonomy, competence and relatedness significantly but moderately correlated among each other which are indications that they are distinct but separate factors of the same construct. These inter-correlations are not unexpected. In fact, it supports the theoretical underpinnings of scale development that factors of the same construct must not relate significantly too high among themselves. Whereas Sheldon and Filka (2008) have reported low inter-dimensional correlations between .22 and .33, Brien et al. (2012) reported moderate inter-factor correlation of between .40 and .47. Silman (2014) however found a wide range of between .28 and .64. In all, findings of the present study corroborate those of previous studies in the nature of inter-relationship among the factors of basic psychological needs.

Factors of psychological empowerment were also well correlated. This is as expected. The development of the Psychological Empowerment Instrument (Spreitzer, 1995a) revealed similar directions reporting low to moderate correlations between .21 and .62 for time 1 and between .24 and .53 for time 2 in the case of insurance sample. In fact, various studies utilising the scale have reported between correlation .34 and .76 (Stander \& Rothmann, 2010), between .13 and .52 for nurses and between .25 and .42 for physicians (Uner \& Turan, 2010), and between .29 and .45 (Albar, García-Ramírez, Jiménez, \& Garrido, 2012).

It would not be out of place to note that employees who have high level of autonomy would also experience meaningfulness in the assigned task, and be self-determined to succeed. Such employee would also feel high in making significant impact and contribution to the organisation. The same goes to employees who have their psychological need of competence satisfied.

Results of the moderated hierarchical multiple regression analysis revealed that satisfaction of basic psychological needs had significant effects on teachers' career commitment, contributing 23.3 percent to the variance in teachers' career commitment. Also, the addition of psychological empowerment to psychological needs satisfaction also accounted for 28.6 percent of the variance in teachers' career commitment with psychological empowerment contributing a significant additional 5.3 percent to the variance in teachers' career commitment.

These findings are revealing. Foremost, the results sustained the potency of psychological needs satisfaction in enhancing career commitment of teachers. Teachers who have their basic work psychological needs fulfilled are liable to be further committed to their career. Although no specific literature could be found to support this assertion, indications from similar studies employing other variants of commitment lend credence to these findings.

However, the results were found to be amazing in that not all dimensions of either psychological needs satisfaction and that of psychological empowerment were good and potent contributors to the variance in teachers' career commitment, leaving a great breach in the findings. The satisfaction of the need for autonomy as observed in this study did not come as a surprise. Autonomy has been observed to involve volition and choice. Individuals with such feelings are expected to relate significantly to psychological empowerment dimensions of impact, meaning, selfdetermination, and competence

The satisfaction of the basic need for competence was also observed in this study to contribute significantly to career commitment. First, as a factor of basic work psychological needs at the first step of the model and later in the secoind step of the model when factors of psychological empowerment were introduced to the model. The potency of competence satisfacton to engender career commitment can not be underplayed. Competence as a basic need involves feeling effective in one's interactions with the environment (Bialis-White, 2013; Skinner, Furrer, Marchand, \& Kindermann, 2008).

Surprising though, it would have been expected that the satisfaction of relatedness would have effect on career commitment. The insignificant contribution of relatedness to the variance in teachers' career commitment as indicated in this study may be revealing and raises questions demanding answers. Relatedness has to do with feeling securely connected with others (Baumesiter \& Leary, 1995).

The significant contribution of impact as a psychological empowerment factor to career commitment of teachers is revealing. Teachers as observed in this study feel committed to their career when they are empowered to make impact on the school and the students than to other 
empowerment dimensions of meaning, competence, and self-determination.

The insignificant contribution of psychological empowerment dimensions of meaning, competence and self-determination might be surprising when the total effect of psychological empowerment as a positive organisational construct, is viewed from the perspective that it should enhance other positive organisational attitudes like job satisfaction, organisational commitment, and work engagement. Whereas few studies (e.g. Mabekoje et al., 2016) have been conducted on the effect of psychological empowerment on career commitment in general, none could be observed to have specifically examined the effects of psychological empowerment dimensions on teachers' career commitment. Literature have proved that psychological empowerment in totality can enhance organisational commitment and job satisfaction (Dehkordi, Kamarani, Ardestani, \& Abdolmanafi, 2011).

In general, psychological empowerment is a significant predictor of, and also contributed incrementally to the effect of basic psychological needs satisfaction on teachers' career commitment. As observed however, it seems that the single factor of psychological empowerment that made this significance was impact empowerment.

\section{Conclusion}

Beyond the satisfaction of work basic psychological needs of autonomy, competence and relatedness, psychological empowerment accounted for significant variance in teachers' career commitment. By this finding, psychological empowerment has predictive and add-on effects on teachers' career commitment beyond the contribution of satisfaction of work basic psychological needs. Specifically, the satisfaction of autonomy and competence as basic psychological needs and impact empowerment factors are compelling in enhancing teachers' career commitment.

\section{Recommendations}

Supported by the findings of the present study, we recommend that basic psychological needs of teachers should be satisfied. School administration should ensure that policies and decisions that would make teachers to be autonomous and have the feeling of competence be enforced. Aside from this, teachers should be psychologically empowered. Activities that would enable teachers to make meaningful impact on students and school organisation should be encouraged.

\section{References}

Albar, M., García-Ramírez, M., Jiménez, A. M. L., \& Garrido, R. (2012). Spanish adaptation of the scale of psychological empowerment in the workplace. The Spanish Journal of Psychology, 15(2), 793-800. doi: 10.5209/rev_SJOP.2012.v15.n2.38891

Aryee, S., \& Tan, K. (1992). Antecedents and outcomes of career commitment. Journal of Vocational Behavior, 40( 331-334. doi: 10.1016/0001-8791(92)90052-2

Ashforth, B. E. (1989). The experience of powerlessness in organizations. Organizational Behavior and Human Decision Processes, 43, 207-242.

Baard, P., Deci, E. L. \& Ryan, R. M. (2004). Intrinsic need satisfaction: A motivational basis of performance and well-being in two work settings. Journal of Applied Social Psychology, 34, 2045-2068.

Ballout, H. I. (2009). Career commitment and career success: Moderating role of self efficacy. Career Development International, 14(7), 655-669. doi: 10.1108/13620430911005708

Baumeister, R. F., \& Leary, M. R. (1995). The need to belong: Desire for interpersonal attachments as a fundamental human motivation. Psychological Bulletin 117(3), 497-529. doi: 10.1037/00332909.117.3.497

Bedeian, A., Kemery, E., \& Pizzolatto, A. (1991). A career commitment and job utility of present job as a predictors of turnover intentions and turnover behavior. Journal of Vocational Behavior. 39, 331-343.

Bialis-White, L. H. (2013). Needs-satisfaction, motivation, and achievement in high school students: testing predictive models by gender and ethnicity. A PhD dissertation of the University of California, Berkeley Retrieved, $11^{\text {th }}$ May, 2017 from http://digitalassets.lib.berkeley.edu/etd/ucb/text/BialisWhite_berkeley_0028E_13679.pdf

Blau, G. J. (1985). Measurement and prediction of career commitment. Journal of Occupational Psychology.58(4), 277-288. doi: 10.1111/j.2044-8325.1985.tb00201.x 
Boudrias, J. S., Gaudreau, P., \& Laschinger, H. K. S. (2004). Testing the structure of psychological empowerment: Does gender make a difference? Education and Psychological Measurement, 64(5), 861877.

Bracht, N. (1999). Health Promotion at the Community Level 2. New Advances. London: Sage Publications.

Brien, M., Forest, J., Mageau, G. A., Boudrias, J., Desrumaux, P., Brunet, L., \& Morin, E. M. (2012). The Basic Psychological Needs at Work Scale: Measurement invariance between Canada and France. Applied Psychology: Health and Well-Being, 4 (2), 167-187. doi:10.1111/j.1758-0854.2012.01067.x

Carless, S. A. (2004). Does psychological empowerment mediate the relationship between psychological climate and job satisfaction? Journal of Business and Psychology. 18(4), 405-425.

Carson, K. D., \& Bedeian, A. G. (1994). Career commitment: Construction of a measure and examination of its psychometric properties. Journal of Vocational Behavior, 44, 237-262. doi: 10.1006/jvbe.1994.1017

Carson, K. D., Carson, P. P., Roe, C. W., Birkenmeier, B. J., \& Philips, J. S. (1999). Four commitment profiles and their relationships to empowerment, service recovery and work attitudes. Public Personnel Management, 28, 1-13.

Cheng, E. W. L., \& Ho, D. C. K. (2001). The influence of job and career attitudes on learning motivation and transfer. Career Development. International, 6(1), 20-27. doi:10.1016/j.edurev.2011.04.001

Ciceka, I., Karabogab, T., \& Sehitoglu, Y. (2016). A new antecedent of career commitment: work to family positive enhancement. Procedia - Social and Behavioral Sciences, 229, 417 - 426

Cohen, A. (1996). On the discriminant validity of the Meyer and Allen (1984) measure of organizational commitment: How does it fit with the work commitment construct? Educational and Psychological Measurement, 56, 494-503

Colarelli, S. M., \& Bishop, R. C. (1990). Career commitment: Functions, correlates, and management. Group and Organization Studies, 15, 158-176. doi: 10.1177/105960119001500203

Day, R., \& Allen, T. (2004). The relationship between career motivation and self-efficacy with protege career success. Journal of Vocational Behavior, 64, 72-91. doi: 10.1016/S0001-8791(03)00036-8

Deci, E. L., \& Ryan, R. M. (1985). Intrinsic motivation and self-determination in human behavior. New York, NY: Plenum.

Deci, E. L., \& Ryan, R. M. (2000). The "what" and "why" of goal pursuits: Human needs and the selfdetermination of behavior. Psychological Inquiry, 11(4), 227-268.

Deci, E. L., \& Ryan, R. M. (2002). Handbook of self-determination research. Rochester, NY: University of Rochester Press.

Deci, E. L., Ryan, R. M., Gagne, M., Leone, D. R., Usunov, J., \& Kornazheva, B. P. (2001). Need satisfaction, motivation, and well-being in the work organizations of a former eastern bloc country: A cross-cultural study of self-determination. Personality and Social Psychology Bulletin, 27(8), 930-942.

Dehkordi, L. F., Kamrani, M. N., Ardestani, H. A. \& Abdolmanafi, S. (2011). Correlation between psychological empowerment with job satisfaction and organizational commitment. Interdisciplinary Journal of Contemporary Research in Business, 3(7), 808-822.

Dewettinck, K., \& Buyens, D. (2006). Linking job motivating potential to frontline employee attitudes and performance: testing the mediating role of psychological empowerment. Ghent University. Vlerick Leuven Gent Management School. Vlerick Leuven Gent Working Paper Series 2006/26 Retrieved on 13th May. 2017 from http://www.vlerick.be/en/2460-VLK/version/default/part/AttachmentData/data/vlgms-wp-200626.pdf

Dewettinck, K., Singh, J., \& Buyens, D. (2003). Psychological empowerment in the workplace: Reviewing the empowerment effects on critical work. Working Paper. Ghent University. Vlerick Leuven Gent Management School. Retrieved on 23rd Feb. 2010 from http://www.FEB.UGent.be/fac/research/WP/Papers/wp_03_210.pdf

Ergeneli, A., Ari, G. S., \& Metin, S. (2007). Psychological empowerment and its relationship to trust in immediate managers. Journal of Business Research, 60, 41-49.

Fields, D. L. (2000). Taking the measure of work: A guide to validated scales for organizational research and diagnosis, Thousand Oaks, CA: Sage Publications.

Freund, A. (2005). Work attitudes of social workers across three sectors of welfare organizations. Journal of Social Service Research, 31, 69-92.

Fu, J. (2011). Understanding career commitment of IT professionals: Perspectives of push-pull-mooring framework and investment model. International Journal of Information Management, 31(3), 279-293.

Goulet, L. R., \& Singh, P. (2002). Career commitment: A reexamination and an extension. Journal of Vocational Behavior, 61(1), 73-91.

Greasley, K., Bryman, A., Dainty, A., Price, A., Soetanto, R. \& King, N. (2005). Employee perceptions of empowerment. Employee Relations. 27(4), 354-368.

Greenhaus, J. H. (1971). An investigation of the role of career salience in vocational behavior, Journal of Vocational Behavior, 1, 209-16.

Greguras, G. J., \& Diefendorff, J. M. (2009). Different fits satisfy different needs: Linking person-environment fit 
to employee commitment and performance using self-determination theory. Journal of Applied Psychology, 94, 465-477.

Hackman, J. R., \& Oldham, G. R. (1980). Work redesign. Reading, MA: Addison-Wesley

Hall, D. T. (1971). A theoretical model of career subidentity development in organizational settings. Organizational Behavior and Human Performance, 6, 50-76. doi: 10.1016/0030-5073(71)90005-5

Harris, J. \& Hagger, M. S. (2007). Do Basic Psychological Needs Moderate Relationships Within the Theory of Planned Behavior? Journal of Applied Biobehavioral Research, 12(1), 43-64. doi: 10.1111/j.17519861.2007.00013.x

Hirsch, E., \& Emerick, S. (2006). Teaching and learning conditions are critical to the success of students and the retention of teachers. Final report on the 2006 teaching and learning conditions survey to the clark county school district and clark county education association, Center for Teaching Quality (CTQ)

Ilardi, B., Leone, D., Kasser, T., \& Ryan, R. M. (1993). Employee and supervisor ratings of motivation: Main effects and discrepancies associated with job satisfaction and adjustment in a factory setting. Journal of Applied Social Psychology, 23, 1789-1805.

Jose, G., \& Mampilly, S. R. (2014). Psychological empowerment as a predictor of employee engagement: an empirical attestation. Global Business Review, 15(1), 93-104

Kalbers, L. P., \& Fogarty, T. J. (1995). Professionalism and its consequences: A study of internal Auditors. Auditing: A Journal of Practice and Theory, 14(1), 64-86.

Keller, K. M. (2005). Being different: A study of relational demogrpahy and the influence of individual and team characteristics. A Masters of Arts dissertation University of Maryland, Retrieved on $11^{\text {th }}$ May, 2017 from http://drum.lib.umd.edu/bitstream/handle/1903/3086/umi-umd-2896.pdf;sequence=1

Kidd, J. M., \& Green, F. (2006). The careers of research scientists: Predictors of three dimensions of career commitment and intention to leave science. Personnel Review, 35(3), 229-251. doi: $10.1108 / 00483480610656676$

Kimolo, K. (2013). The relationship between employee empowerment practices and employee performance in regional development authorities in Kenya. Degree of Masters of Business Administration (MBA). School of Business Administration. University of Nairobi.

Koberg, C. S., Senjem, J. C., \& Goodman, E. A. (1999). Antecedents and outcomes of empowerment: Empirical evidence from the health care industry. Group and Organizational Management, 24(1), 71-91.

Kosar, R. \& Mehdi Raza Naqvi, S. M. (2016) Psychological empowerment and employee behaviors: employee engagement as mediator and leader-member exchange as moderator. Journal of International Business Research and Marketing, 1(6), 24-30. doi: 10.18775/jibrm.1849-8558.2015.16.3004 Retrieved $13^{\text {th }}$ May, 2017 from http://researchleap.com/wp-content/uploads/2016/09/Psychological-Empowerment-andEmployee-Behaviors-Employee-Engagement-As-Mediator-and-Leader-Member-Exchange-asModerator.pdf

Lee, K., Carswell, J. J., \& Allen, N. J. (2000). A meta-analytic review of occupational commitment: Relations with person- and work-related variables. Journal of Applied Psychology, 85(5), 799-811. doi:10.1037/00219010.85.5.799

Liden, R. C., \& Arad, S. (1996). A power perspective of empowerment and work groups: Implication for HRM research. In G.R. Ferris (Ed.), Research in personnel and HRM, (vol. 14: pp. 205-252). Greenwich, CT: JAI Press.

Liden, R. C., Wayne, S. J., \& Sparrowe, R. T. (2000). An examination of the mediating role of psychological empowerment on the relations between the job, interpersonal relationships, and work outcomes. Journal of Applied Psychology, 85, 407-416

Liden, R. C., Wayne, S. J., \& Stilwell, D. (1993). A longitudinal study on the early development of leadermember exchange. Journal of Applied Psychology, 78, 662-674.

London, M. \& Stumpf, S. A. (1982). Managing Careers. MA: Addison-Wesiey.

London, M. (1983). Toward a theory of career motivation. Academy of Management Review, 8, 620-30.

Lynch, M., Plant, R., \& Ryan, R. M. (2005). Psychological needs and threat to safety: Implications for staff and patients in a psychiatric hospital for youth. Professional Psychology Research and Practice, 36, 415-425.

Mabekoje, S. O., Azeez, R. O., Okunuga, O. O., \& Bamgbose, A. O. (2016). Does basic work needs satisfaction mediate between psychological empowerment and career commitment of teachers? Academic Journal of Interdisciplinary Studies, 5(3), 187-199. Doi:10.5901/ajis.2016.v5n3p187

Mayer, D., Bardes, M., \& Piccolo, R. (2008). Do servant leaders help satisfy follower needs? An organizational justice perspective, European Journal of Work and Organizational Psychology, 17(2), 180-97.

Najafi, S., Noruzy, A., Azar, H. K., Nazari-Shirkouhi, S., \& Dalvand, M. R. (2011). Investigating the relationship between organizational justice, psychological empowerment, job satisfaction, organizational commitment and organizational citizenship behavior: An empirical model. African Journal of Business Management, 5(13), 5241-5248. doi: 10.5897/AJBM10.1505

Nel, T., Stander, M. W., Latif, J. (2015). Investigating positive leadership, psychological empowerment, work engagement and satisfaction with life in a chemical industry. SA Journal of Industrial Psychology/SA 
Tydskrif vir Bedryfsielkunde, 41(1), Art. \#1243, 13 pages. doi: 10.4102/sajip.v41i1.1243

Okurame, D. E. (2012). Linking work-family conflict to career commitment: the moderating effects of gender and mentoring among Nigerian civil servants. Journal of Career Development, 39(5), 423-442

Onyoin, M. (2011). Locus of control, self efficacy, career commitment and career turnover intentions among teaching staff: A case of public universities in Uganda. A MBA Dissertation of Makerere University Retrieved, $11^{\text {th }}$ May, 2017 from http://makir.mak.ac.ug/handle/10570/2408

Ozaralli, N. (2003). Effects of transformational leadership on empowerment and team effectiveness. Leadership \& Organization Development Journal, 24(5/6), 335-344

Parker, L. (1993). When to fix it and when to leave: Relationships among perceived control, self-efficacy, dissent, and exit. Journal of Applied Psychology, 78, 949-959

Poon, J. M. L. (2004). Career commitment and career success: Moderating role of emotion perception. Career Development International 9(4), 374-390.

Prati, G. \& Zani, B. (2013). The relationship between psychological empowerment and organizational identification. Journal of Community Psychology, 41(7), 851-866

Rissel, C. (1994). Empowerment: the holy grail of health promotion? Health Promotion International, 9(1), 39-47.

Ryan, R. M. (1995). Psychological needs and the facilitation of integrative processes. Journal of Personality, 63, 397-427.

Ryan, R. M., \& Deci, E. L. (2000). Self-determination theory and the facilitation of intrinsic motivation, social development, and well-being. American Psychologist, 55, 68-78.

Saeidi, M. \& Asgari, M. H. (2016). The relationship between psychological empowerment and job involvement of employees in Islamic Azad University of Tonekabon branch. Journal of Current Research in Science. $S(2), 2016: 451-458$.

Seibert, S. E., Silver, S. R. \& Randolph, W. A. (2004). Taking empowerment to the next level: A multiple-level model of empowerment, performance and satisfaction. Academy of Management Journal. 47(3), 332-349.

Shapira-Lishchinsky, O., \& Tsemach, S. (2014). Psychological empowerment as a mediator between teachers' perceptions of authentic leadership and their withdrawal and citizenship behaviors. Educational Administration Quarterly, 50(4) 675-712. doi: 10.1177/0013161X13513898

Sheldon, K. M. \& Filak, V. (208). Manipulating autonomy, competence, and relatedness support in a gamelearning context: New evidence that all three needs matter. British Journal of Social Psychology, 47, $267-$ 283

Silman, F. (2014). Work-related basic need satisfaction as a predictor of work engagement among academic staff in Turkey. South African Journal of Education, 34 (3), 1 Art. \# 874, 5 pages, http://www.sajournalofeducation.co.za

Skinner, E., Furrer, C., Marchand, G., \& Kindermann, T. (2008). Engagement and disaffection in the classroom: Part of a larger motivational dynamic? Journal of Educational Psychology, 100, 765-781. doi: $10.1037 / \mathrm{a} 0012840$

Somers, M., \& Birnbaum, D. (1998). Work-related commitment and job performance: It's also the nature of the performance that counts. Journal of Organizational Behavior, 19(6), 621-634.

Somers, M., \& Birnbaum, D. (2000). Exploring the relationship between commitment profiles and work attitudes, employee withdrawal, and job performance. Public Personnel Management, 29(3), 353-366. doi: $10.1177 / 009102600002900305$

Spreitzer, G. M. (1995a). Psychological empowerment in the workplace: Dimensions, measurement, and validation. Academy of Management Journal, 38(5), 1442-1465.

Spreitzer, G. M. (1995b). An empirical test of a comprehensive model of intrapersonal empowerment in the workplace American Journal of Community Psychology, 23(5), 601-629. doi:10.1007/BF02506984

Spreitzer, G. M. (1996). Social structure characteristics of psychological empowerment. Academy of Management Journal, 39(2), 483-504.

Spreitzer, G. M., Kizilos, M. A., \& Nason, S. W. (1997). A dimensional analysis of the relationship between psychological empowerment and effectiveness, satisfaction, and strain. Journal of Management, 23(5), 679-704.

Stander, M. W., \& Rothmann, S. (2010). Psychological empowerment, job insecurity and employee engagement. SA Journal of Industrial Psychology/SA Tydskrif virBedryfsielkunde, 36(1), Art. \#849, 8 pages. doi: 10.4102/sajip.v36i1.849

Staw, B. M. (1984). Organizational Behavior: A review and reformation of the field's outcome variables. Annual Review of Psychology, 35, 627-666

Tengland, P. A. (2007). Empowerment: A goal or a means for health promotion. Medicine, Health Care and Philosophy, 10(2), 197-207.

Thomas, K. W., \& Tymon, W. G. (1994). Does empowerment always work: Understanding the role of intrinsic motivation and personal interpretation. Journal of Management Systems, 6, 39-54

Thomas, K. W., \& Velthouse, B. A. (1990). Cognitive elements of empowerment. Academy of Management Review, 15: 666-681. 
Uner, S., \& Turan, S. (2010). The construct validity and reliability of the Turkish version of Spreitzer's psychological empowerment scale. BMC Public Health 2010, 10:117 http://www.biomedcentral.com/14712458/10/117

Van Den Broeck, A., Vansteenkiste, M., \& De Witte, H. (2008). Self-determination theory: A theoretical and empirical overview in occupational health psychology. In J. Houdmont, \& S. Leka (Eds.), Occupational health psychology: European perspectives on research, education, and practice (Vol 3, pp. 63-88). Nottingham: Nottingham University Press.

Van den Broeck, A., Vansteenkiste, M., De Witte, H., \& Lens, W. (2008). Explaining the relationships between job characteristics, burnout and engagement: The role of basic psychological need satisfaction. Work \& Stress. 22, 277-294

Van den Broeck, A., Vansteenkiste, M., De Witte, H., Soenens, B., \& Lens, W. (2010). Capturing autonomy, competence, and relatedness at work: Construction and initial validation of the Work-related Basic Need Satisfaction scale. Journal of Occupational and Organizational Psychology, 83, 981-1002.

Vansteenkiste, M., Neyrinck, B., Niemiec, C., Soenens, B., De Witte, H., \& Van den Broeck, A. (2007). On the relations among work value orientations, psychological need satisfaction, and job outcomes: A selfdetermination theory approach. Journal of Occupational and Organizational Psychology, 80, 251-277.

Wallerstein, N. (1992). Powerlessness, Empowerment and health: Implications for health promotion programs. American Journal of health promotion, 6(3), 197-205.

Wenzlaff, T. L., \& Wieseman, K. C. (2004). Teachers need teachers to grow. Teacher Education Quarterly, 31 (2), 113-124.

Wiener, Y., \& Vardi, Y. (1980). Relationships between job, organization, and career commitments and work outcomes: An integrative approach. Organizational Behavior and Human Performance, 26, 81-96.

Wilson, P. M., Longley, K., Muon, S., Rodgers, W. M., \& Murray, T. C. (2006). Examining the contributions of perceived psychological need satisfaction to well-being in exercise. Journal of Applied Biobehavioral Research, 11(3-4), 243-264. doi: 10.1111/j.1751-9861.2007.00008.x 